\title{
Investigation of HIV/AIDS prevalence and associated risk factors among female sex workers from 2010 to 2017: a meta-analysis study
}

This article was published in the following Dove Press journal: HIVIAIDS - Research and Palliative Care

\section{Owrang Eilami'}

Ali Nazari ${ }^{2}$

Majid Dousti ${ }^{3}$

Fatemeh Sayehmiri $^{4}$

Maryam Ghasemi ${ }^{5}$

'Infectious Disease, Faculty of Medicine, Yasuj University of Medical Sciences, Yasuj, Iran; ${ }^{2}$ Faculty of Medicine, llam University of Medical Sciences, Ilam, Iran; ${ }^{3}$ Department of Parasitology, Faculty of Medicine, Shiraz University of Medical Sciences, Fars, Iran; ${ }^{4}$ Student Research Committee, Proteomics Research Center, Shahid Beheshti University of Medical Sciences, Tehran, Iran; ${ }^{5}$ Faculty of Medicine, Shahid Beheshti University of Medical Sciences, Tehran, Iran
Correspondence: Ali Nazari

Department of Infectious Disease, School of Medicine, Ilam University of Medical Sciences, Pajohesh Street, Ilam 6939177143, Iran

Email nazari-a@medilam.ac.ir
Objectives: Female sex workers (FSW) are highly at risk of HIV, and can potentially transmit the human immunodeficiency virus (HIV) in different societies.

Study design: The aims of the present study were to investigate the prevalence of HIV/ AIDS and associated risk factors among FSW between 2010 and 2017 using a systematic literature review and meta-analysis approach.

Methods: International databases were searched, including ISI Web of Science, Embase, PubMed, and Scopus. Using the appropriate keywords, relevant studies published on the HIV/AIDS prevalence among FSW between 2010 and 2017 were identified. Afterwards, the information was extracted and analyzed by STATA version 14.

Results: Thirty-seven studies were found eligible for inclusion in this research, encompassing a total of 46,657 subjects. The results revealed that the global prevalence of HIV/AIDS among FSW was 2.17 (95\% CI=1.37-3.14).

Conclusion: These findings demonstrated the high prevalence of HIV/AIDS among FSWs worldwide. Accordingly, strict educational and interventional programs should be implemented globally to reduce HIV/AIDS prevalence among this group, as well as to prevent probable HIV transmission.

Keywords: prevalence, HIV/AIDS, risk factors, immunodeficiency, female sex workers

\section{Introduction}

The number of individuals infected with human immunodeficiency virus (HIV-1) continues to increase worldwide. Based on the latest statistics, there are nearly 40 million HIV-positive people in the world, while the developing countries contain $95 \%$ of them. ${ }^{1}$ It is estimated that 14 thousand individuals are being infected with the HIV each day worldwide and more than 30 million people have lost their lives because of the AIDS, since the first HIV positive patient was identified. Many studies suggested that the most common mode of HIV transmission is associated with sexual affairs and relationships in the US; while, in Eastern Europe, especially Ukraine and Central Asia, intravenous drug use has been reported as the main mode of transmission. ${ }^{2,3}$ Moreover, more than half of the HIV-positive individuals were identified to be female. Intravenous illegal drug use and unprotected sex contribute as the main risk factors for HIV transmission among this group. ${ }^{4,5}$ However, various social, economic, and political factors can also further affect the prevalence of HIV/AIDS. ${ }^{6}$ For instance; the main source of HIV infection in developed countries such as the UK and the US is homosexuality, while high-risk sexual 
Table I Demographic characteristics of studies involved in meta-analysis

\begin{tabular}{|c|c|c|c|c|c|c|c|}
\hline Authors & $\begin{array}{l}\text { Year of } \\
\text { publication }\end{array}$ & Country & $\begin{array}{l}\text { Sample } \\
\text { size }\end{array}$ & $\begin{array}{l}\text { Age } \\
\text { (years) }\end{array}$ & $\begin{array}{l}\text { HIV prevalence in } \\
\text { FSWs (\%) }\end{array}$ & $\begin{array}{l}\text { Condom } \\
\text { use }(\%)\end{array}$ & $\begin{array}{l}\text { Used illicit } \\
\text { drugs (\%) }\end{array}$ \\
\hline Abdelrahim ${ }^{30}$ & 2010 & Sudan & 321 & 28 & 0.9 & 66.3 & \\
\hline Mahfoud et al ${ }^{17}$ & 2010 & Lebanon & 135 & & 0 & 39 & \\
\hline Todd et $\mathrm{al}^{3 !}$ & 2010 & Afghanistan & 520 & 23.3 & 0.19 & 38.2 & 6.9 \\
\hline Strathdee et $\mathrm{al}^{32}$ & 2011 & Mexico & 620 & 33 & 5.3 & 30 & 33 \\
\hline Braunstein et $\mathrm{al}^{33}$ & 2011 & Rwanda & 397 & 24 & 3.5 & 18 & \\
\hline Vandepitte et $\mathrm{al}^{16}$ & 2011 & Uganda & 482 & & 38 & 33.9 & \\
\hline Xu et $\mathrm{al}^{34}$ & 2011 & China & 1,642 & & 1.8 & & \\
\hline Ramesh et $\mathrm{al}^{35}$ & 2012 & India & 2,042 & $<30$ & 2.7 & & \\
\hline Vuylsteke et $\mathrm{al}^{24}$ & 2012 & $\mathrm{Co}^{\wedge}$ te d'lvoire & 1,110 & & 26.6 & 26.4 & \\
\hline Goldenberg et $\mathrm{al}^{36}$ & 2014 & Canada & 508 & & 11.22 & 21.24 & 1.6 \\
\hline Schwartz et $\mathrm{al}^{37}$ & 2015 & Co^te d'lvoire & 466 & & 0.97 & 19 & \\
\hline Deuba et $\mathrm{al}^{38}$ & 2016 & Nepal & 610 & & I & 78 & 94.8 \\
\hline Afzal et $\mathrm{al}^{25}$ & 2017 & South Africa & 97 & 36 & 32.9 & & \\
\hline Pando et $\mathrm{al}^{39}$ & 2013 & Argentina & 1,255 & 33.5 & 2 & 17.6 & \\
\hline Qyra et $\mathrm{al}^{40}$ & 2011 & Albania & 90 & 28 & 1.08 & 35 & \\
\hline Argento et $\mathrm{al}^{4 \mathrm{I}}$ & 2017 & Canada & 455 & 36 & 2.69 & & 2.93 \\
\hline Corneli et $\mathrm{al}^{42}$ & 2016 & Kenya & 172 & 29 & 18 & 33.9 & \\
\hline Decker et al ${ }^{43}$ & 2012 & Russia & 147 & $17-40$ & 4.8 & 78.9 & \\
\hline Decker et $\mathrm{al}^{44}$ & 2016 & Cameroon & 1,817 & $\geq 18$ & 5.1 & 59.2 & \\
\hline Fan et $\mathrm{al}^{45}$ & 2015 & China & 622 & $>16$ & 1.1 & 66.2 & 2.1 \\
\hline Forbi et $\mathrm{al}^{26}$ & 2011 & Nigeria & 900 & $18-35$ & 37.2 & 46.7 & \\
\hline Couture et $\mathrm{al}^{46}$ & 2011 & Cambodia & 160 & $<29$ & 23 & 85.7 & \\
\hline Le et $\mathrm{a}^{47}$ & 2015 & Vietnam & 5,298 & $\geq 18$ & 1.76 & & \\
\hline Dias et $\mathrm{al}^{48}$ & 2015 & Portugal & 853 & $\geq 18$ & 7.4 & & 18.1 \\
\hline Magnani et al $^{49}$ & 2010 & Indonesia & 5,947 & 28 & 10.5 & & \\
\hline Medhi et $\mathrm{al}^{50}$ & 2012 & India & 426 & $\geq 18$ & 11.6 & & 36.7 \\
\hline Wirtz et $\mathrm{al}^{51}$ & 2015 & Russia & 754 & & 6.7 & & 11 \\
\hline Silitonga et $\mathrm{al}^{52}$ & 2011 & Indonesia & 3,086 & & 1.4 & & \\
\hline Wang et $\mathrm{al}^{53}$ & 2011 & China & 751 & & 4.9 & & 8.8 \\
\hline Wayal et $\mathrm{al}^{54}$ & 2011 & India & 326 & & 26 & & \\
\hline Kang et $\mathrm{al}^{18}$ & 2013 & China & 3,326 & & 0 & & \\
\hline Platt et $\mathrm{al}^{55}$ & 2011 & UK & 268 & & 1.1 & & \\
\hline Chen et $\mathrm{al}^{56}$ & 2012 & China & 5,322 & $>16$ & 0.54 & & \\
\hline Zhu et al ${ }^{57}$ & 2017 & China & 589 & $>16$ & 2.74 & & \\
\hline Lu et al ${ }^{58}$ & 2017 & Tibet China & 2,000 & & 5.81 & & \\
\hline Okafor et $\mathrm{al}^{59}$ & 2017 & Nigeria & 1,050 & $15-24$ & 15.5 & & \\
\hline Kakchapati et al ${ }^{60}$ & 2016 & Nepal & 2,093 & & 1.8 & & \\
\hline
\end{tabular}

relationships (including polygamy, having intercourse with sex workers, and unprotected sexual relationships) in African countries and intravenous drug use in Eastern and Southeastern countries mainly contributed to the transmission of HIV. ${ }^{7-10}$ Several studies have indicated high levels of HIV prevalence among female sex workers (FSW) who earn money in exchange for providing sexual services to their clients. ${ }^{11}$ Compared with the general population, it seems that FSW are more susceptible to ADIS due to the different factors of unprotected sexual intercourse, sex with multiple partners, and other probable high risk sexual relationships. ${ }^{12}$

Moreover, as is expected, FSW can extremely transmit HIV/AIDS. Thus, providing and implementing educational and interventional policies as well as preventive programs targeting this group could greatly reduce the prevalence of HIV/AIDS within different societies. ${ }^{12}$

Over the past two decades remarkable successes have been achieved in reducing the risk of contamination with HIV, as well as the associated morbidity, mortality, and 


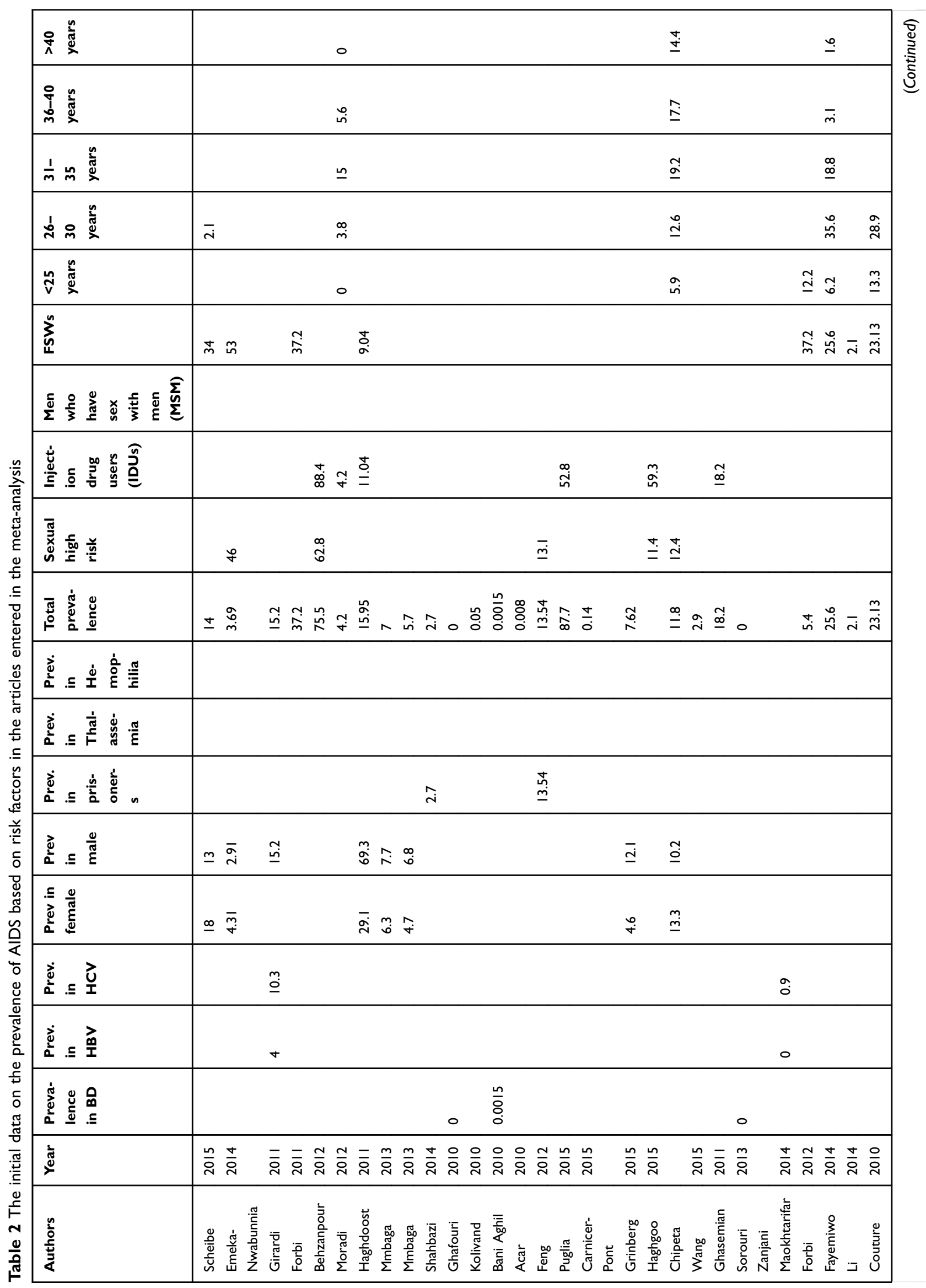




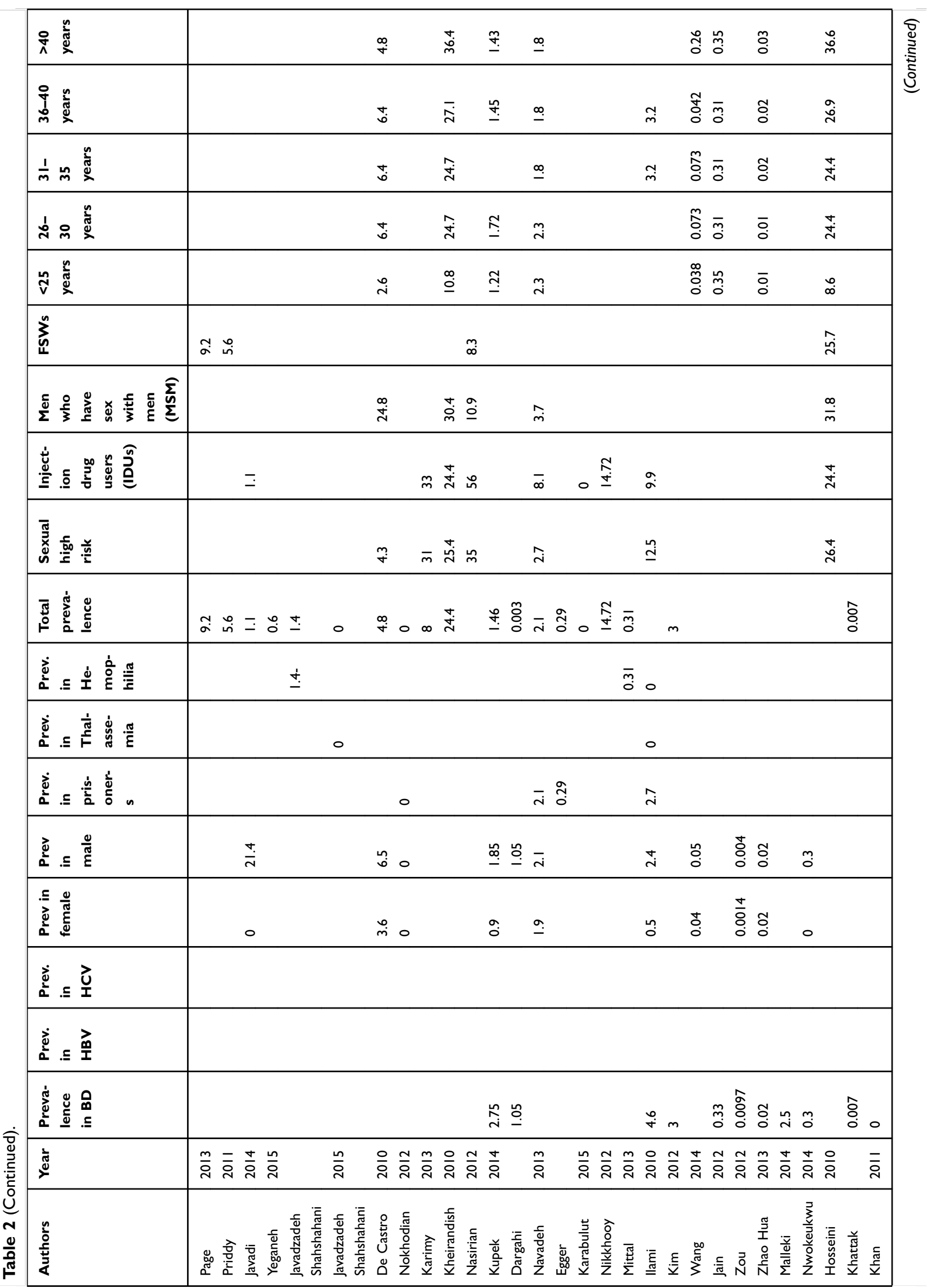




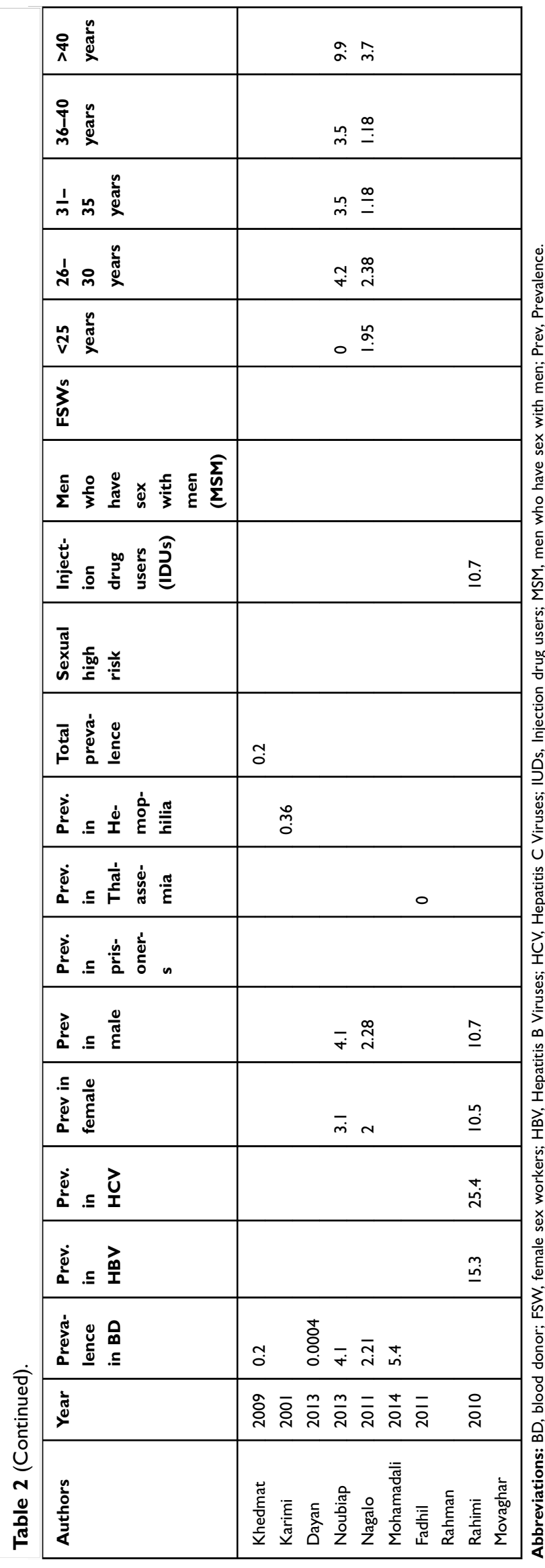

stigma, and indisputable improvements have been made in the quality-of-life of people living with HIV. ${ }^{13}$ In this regard, the Joint United Nations has also developed a Program on HIV/AIDS (UNAIDS) with the approach to diagnose $90 \%$ of all HIV-positive individuals, provide antiretroviral treatments (ART) for $90 \%$ of diagnosed persons, and to attain viral suppression for $90 \%$ of treated individuals by 2020 . It is believed that this could result in viral suppression in at least $73 \%$ of infected people, which is a necessary step in order to end the AIDS epidemic by $2030 .^{2}$ However, according to the recent reports by the national HIV program, it is indicated that the 90-90-90 targets agenda is unrealistic for $2020 .^{14}$ About 2.1 million new HIV-positive cases were diagnosed in 2015, and such a high rate of incidence can further fuel the epidemics of this disease.

Since the treatment course of the disease and providing supportive care are difficult, highly costed, and complicated, the most important and feasible strategy could be the implementation of preventative measures such as education, counseling, and changing behavioral patterns. ${ }^{15}$ To achieve this goal, knowledge about the modes of disease transmission and awareness of target groups who are more vulnerable to AIDS or the groups who are mostly involved in the disease prevalence and other risk factors is needed. Thus, in the present study we aimed to determine HIV/ AIDS prevalence rates in FSW, as well as to study the related risk factors from 2010 to 2017 by a systematic review of literature and meta-analysis approach.

\section{Research method}

\section{Data sources and search strategy}

The international databases of ISI Web of Science, Embase, PubMed, and Scopus were searched carefully to find English language studies which reported the HIV/AIDS prevalence and its associated risk factors among FSW between the years of 2010 and 2017. The searches were done using the appropriate keywords of HIV/AIDS, immunodeficiency, risk factors, sex workers, and female sex workers (FSW), along with all possible word combinations. Moreover, additional manual searches were performed using reference lists of relevant articles to find further papers which may be missed in the electronic searching process.

\section{Study selection (inclusion and exclusion criteria)}

All cross-sectional and descriptive or group studies investigating the relationship between each or a group 

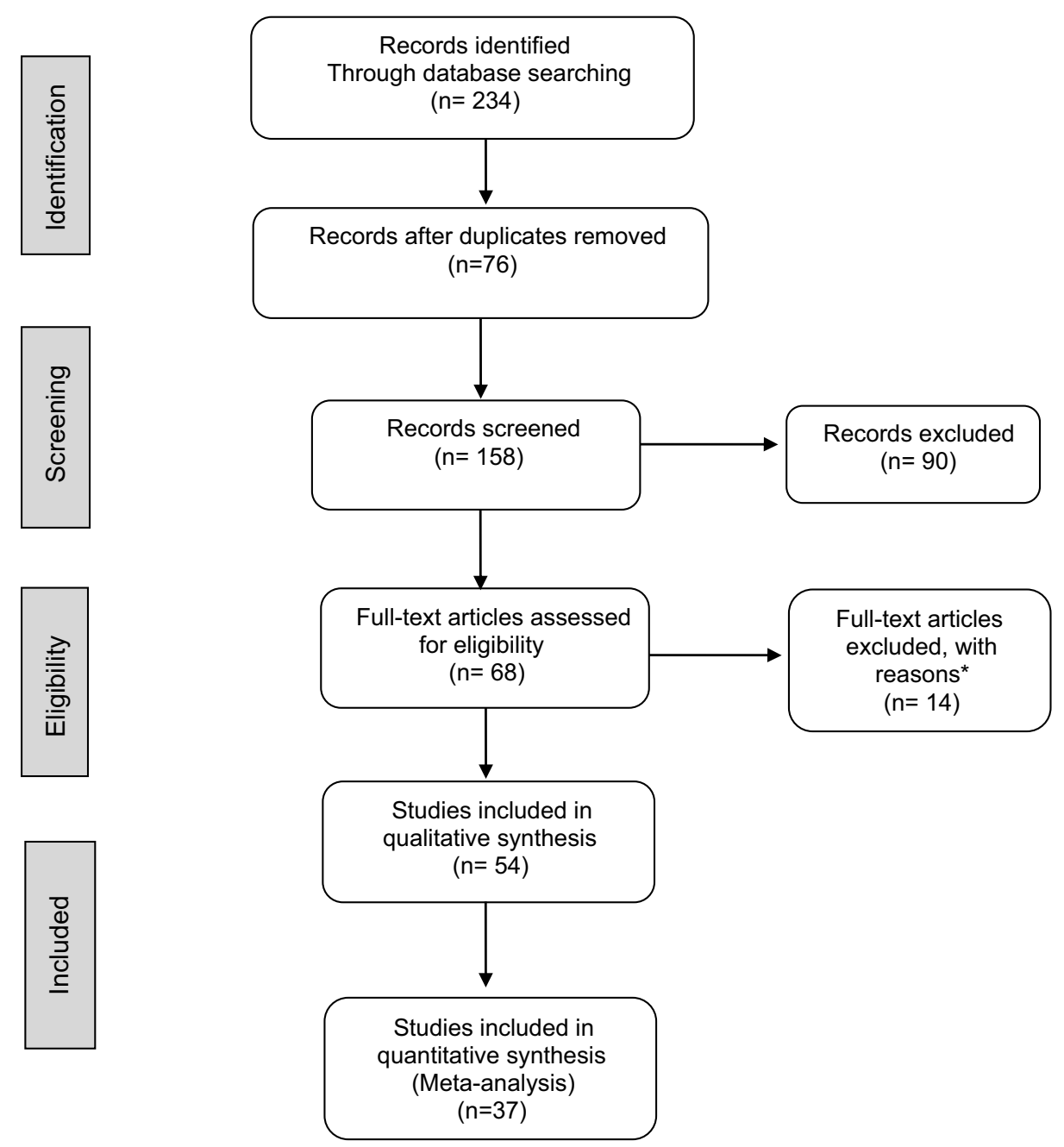

Figure I Prisma flow diagram illustrating selection of articles.

Note: 14 articles were omitted due to the inaccessibility of their full text.

of risk factors and HIV/AIDS prevalence were considered in order to review their full texts. We examined the selected articles for relevance in three phases of title, abstract, and full text review. The main inclusion criterion for this study was relevance for "HIV/AIDS prevalence and associated risk factors among FSWs". Also, the studies with inadequate information, investigations other than descriptive research, review studies, abstracts published in congresses, non-English language published articles, systematic studies, meta-analyzes, and repeated investigations (duplications) were excluded from data analysis (Table 2). For all of the selected research articles, the data were extracted on name of the first author, the year of publication, study context, sample size, continent and the country of origin, and HIV/AIDS prevalence based on each of the risk factors (Table 1). Two of the authors searched for all the relevant articles and then provided a list of abstracts upon completion of the search. At this stage, 234 potentially relevant articles on the HIV/AIDS prevalence and its associated risk factors among FSW were entered into the initial list. Afterwards, all the research articles were individually reviewed; and 76 of them were excluded because of being duplicates. Another 90 papers were also excluded because they were published before 2010. Moreover, 14 articles were omitted due to the inaccessibility of their full text, and 17 studies were excluded because they were found to be meta-analyses and review articles rather than original publications. Finally, 37 research articles were selected to be eligible to enter into this meta-analysis (Figure 1).

\section{Data extraction}

The 37 articles were selected as most relevant and highquality studies for this meta-analysis. Then, a checklist of necessary information was provided for all the 


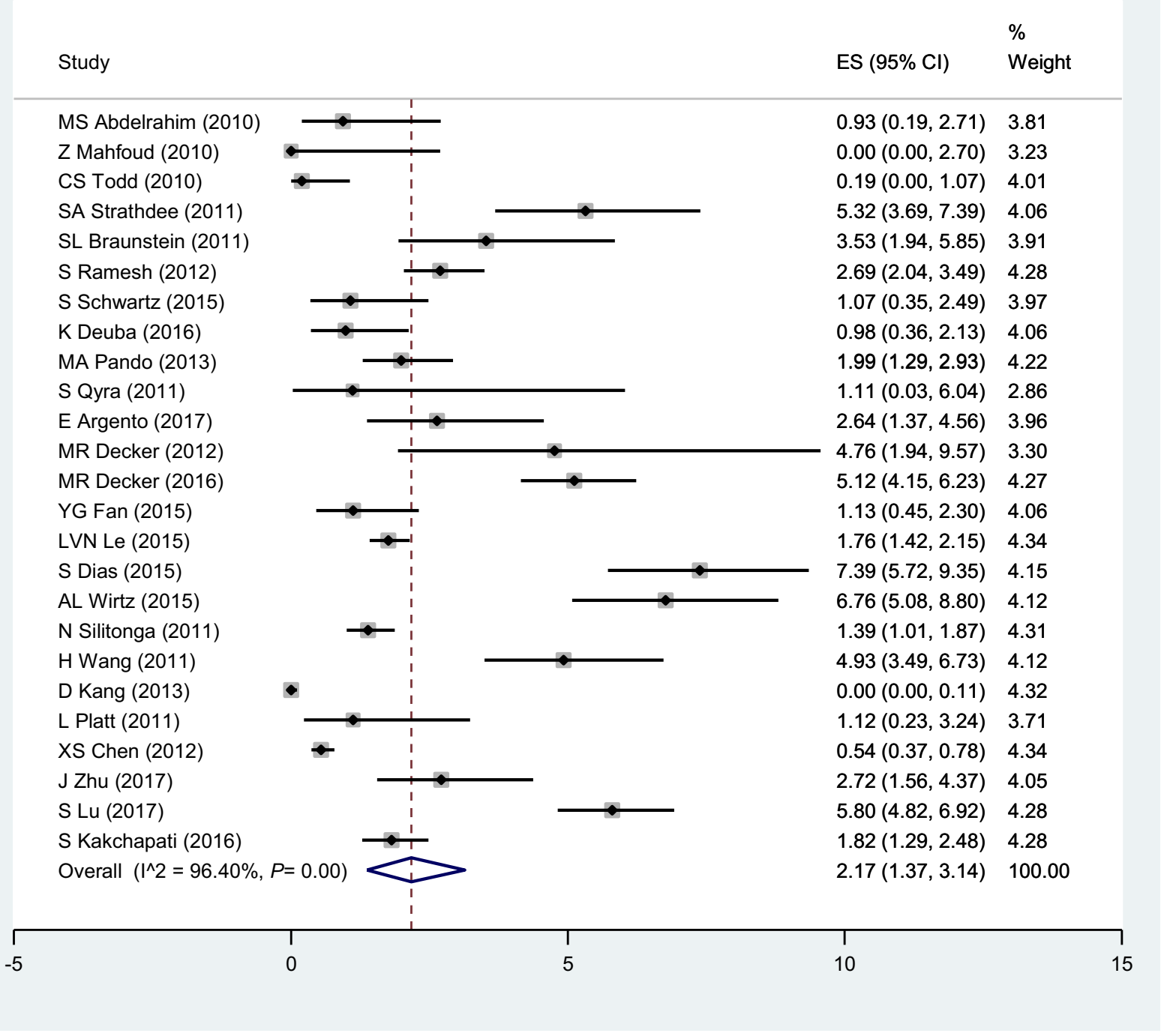

Figure 2 The prevalence of HIV among sex workers based on the random effects model. The midpoint of each section estimates the prevalence and length of the line, the $95 \%$ confidence interval in each study, and the diamond shows the prevalence of HIV among sex workers in this study.

studies. The checklist contained information on the different items needed for the study (the name of the first author, year of the publication, study context, sample size, a variety of risk factors, HIV/AIDS prevalence rate, etc.).

\section{Statistical analysis}

In order to calculate the variance of each study and the combination of HIV/AIDS prevalence and its risk factors in FSWs, binomial distribution and weighted mean were used, respectively. Thus, each study was weighted in accordance with its variance. Given the large differences in the HIV prevalence within the different studies (the heterogeneity of research articles) and significance of the heterogeneity index $\left(\mathrm{I}^{2}\right)$, a random effects model was employed in this meta-analysis. We used metaprop command in STATA to perform random effects meta-analysis (meta-analysis of proportions) and calculate the pooled estimate of proportions with the corresponding $95 \%$ confident intervals. Moreover, the Freeman-Tukey Double Arcsine Transformation (Freeman, M. F., and Tukey, J. W. 1950) was used to stabilize the variances when the proportions were close to 0 or 1. Metaprop requires two variables in the format $\{\mathrm{n}, \mathrm{N}\}$ such that $P=\mathrm{n} / \mathrm{N}$ to be declared.

\section{Findings}

In this meta-analysis, we examined 37 eligible original articles on HIV/AIDS prevalence among FSWs 


\begin{tabular}{l|rrr} 
Study \\
ID
\end{tabular}

Figure 3 The prevalence of condom use in sex with clients by sex workers based on the random effects model. The midpoint of every line estimates the prevalence in each study, and the diamond shows the overall prevalence for all study.

published from 2010 to 2017, encompassing a total number of 46,657 FSWs. The overall findings showed that HIV/AIDS prevalence among FSWs was equal to $8 \%$. But, after sensitivity analysis and deletion of outlier studies, the prevalence rate of HIV among FSWs was found to be 2.17 (95\% CI=1.37-3.14) (Figure 2).

Herein, the prevalence of condom use among FSWs was obtained to be $0.42 \%(95 \% \mathrm{CI}=0.29-0.55)$ (Figure 3$)$. Moreover, the intravenous drug use prevalence in FSW was $0.07 \%(95 \% \mathrm{CI}=0.01-0.14)$ (Figure 4).

\section{Publication bias}

The Begg's funnel plot was used to assess the presence of publication bias in the studies. To this end, the studies were sorted from the most precise to the least precise (according to standard error), and then a cumulative random effect meta-analysis was run to realize if there was any trivial change in effect size (Figure 5). Trim and fill analysis was done as well to check the effects of missing studies on the overall results and adjust the final pooled effect size.

\section{Discussion}

FSW have been considered as the most important group for HIV/AIDS transmission and propagation within societies; however, associated risk factors and the prevalence of HIV among this population have not been systematically evaluated in the past decade. In the present study, the overall HIV/AIDS prevalence among FSWs between 2010 and 2017 was obtained to be 2.17 (95\% CI=1.37-3.14). The highest rate of HIV/AIDS prevalence among FSWs was reported as $38 \%$ by Vandepitte et $\mathrm{al}^{16}$ in Uganda. However, no HIV-positive individual was identified among FSW in the studies conducted by Mahfoud et $\mathrm{al}^{17}$ in Lebanon and Kang et $\mathrm{al}^{18}$ in China; the lowest HIV/AIDS prevalence among this group. Recently, antiretroviral therapy (ART) has been shown to be able to induce a high remission rate among HIV positive individuals. In this regard, it has been strongly confirmed that ART could result in desirable outcomes both in treatment and prevention of HIV by; 1 ) improving the health condition of individuals who already diagnosed with HIV and 2) preventing the 
Study

ID
ES $(95 \% \mathrm{Cl}) \quad$ Weight

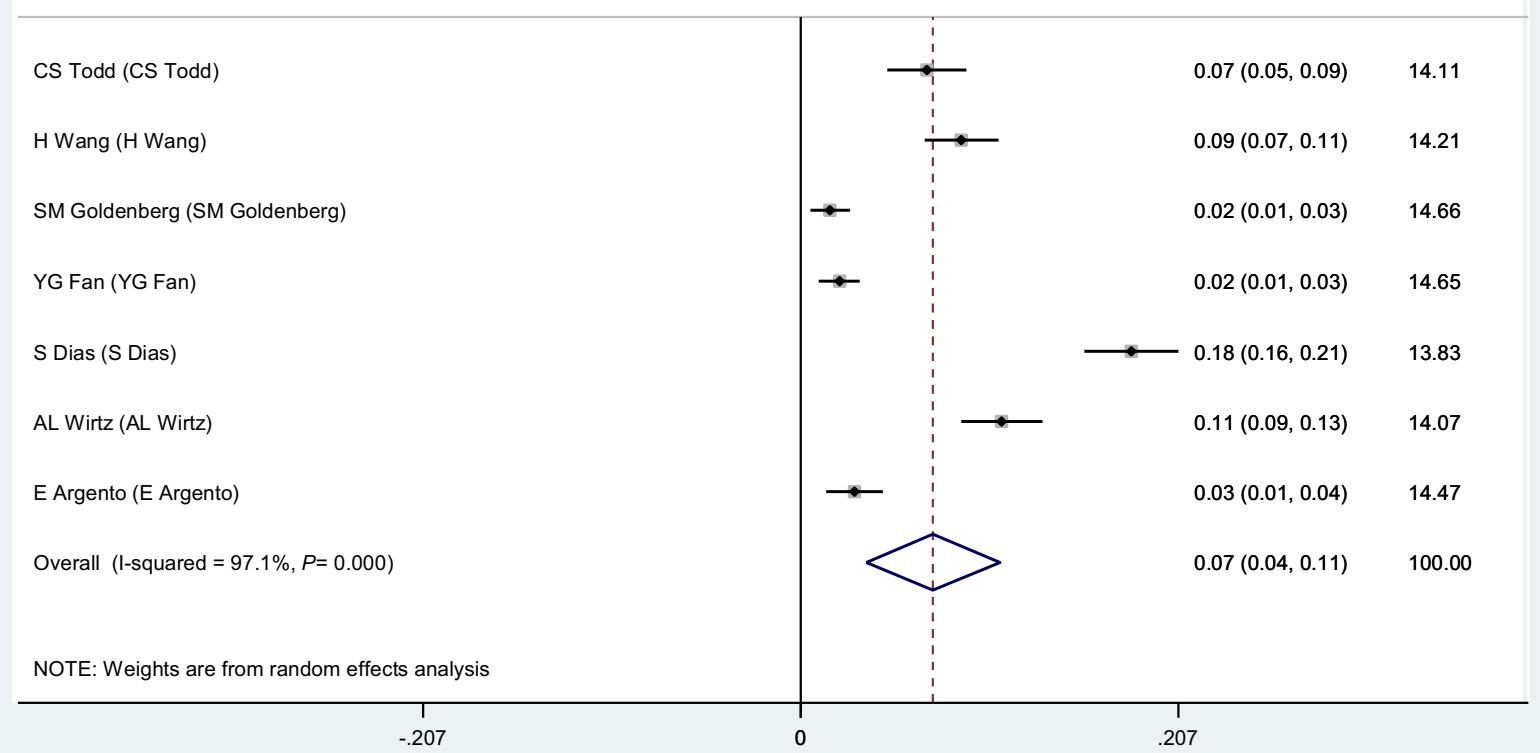

Figure 4 The prevalence of injecting drug use in sex workers based on the random effects model. The midpoint of each section of the line estimated prevalence in each study, and the diamond indicates the prevalence of injecting drug use for all studies.

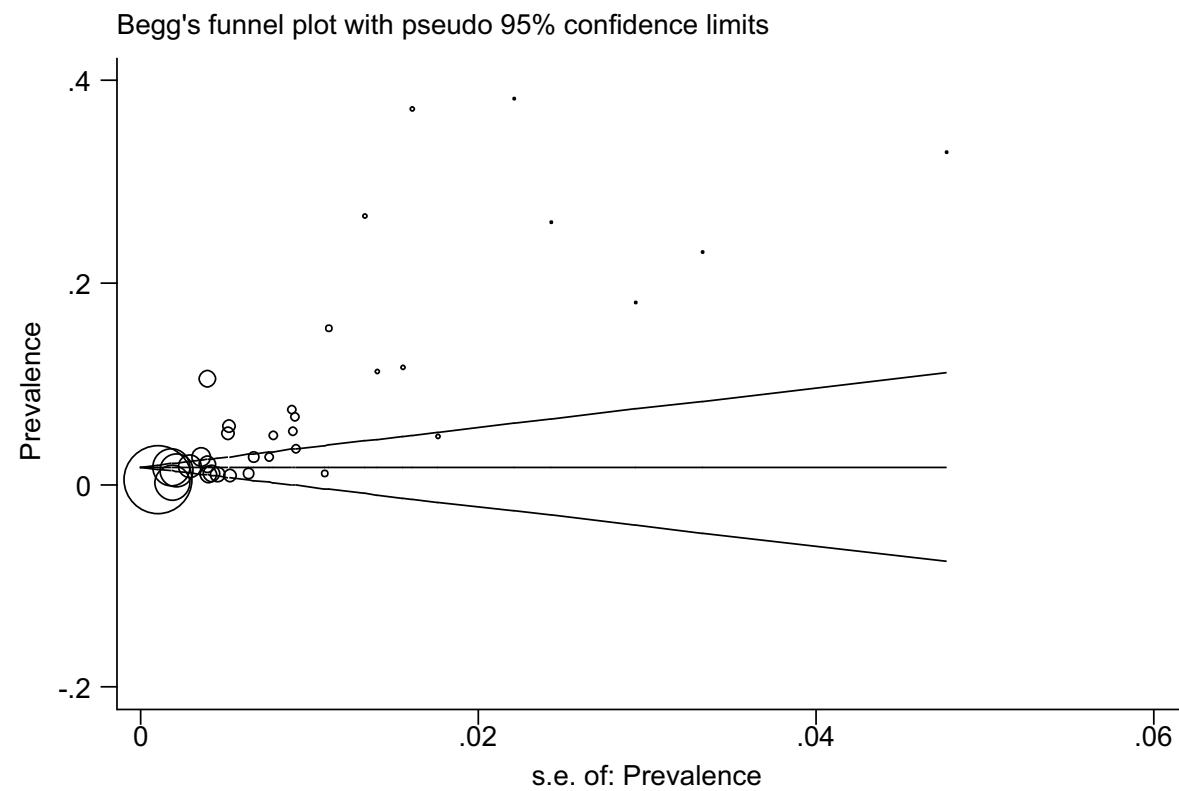

Figure 5 Begg's funnel plot for publication bias. 
ongoing HIV transmissions. ${ }^{20,21}$ In accordance, universal coverage of ART was recommended for all HIV positive patients by WHO. However, our results showed a different pattern of HIV prevalence among FSW within different countries. According to these findings, we assumed that the preventive measures and treatment procedures should be applied context-specific and in compliance with national approaches to combat with HIV. $^{19}$

Due to the criminal nature of sex work, a limited number of researches have developed on this subject and no special services are provided for FSW. To address this issue, the South African National AIDS Council, in 2013, launched the strategy of the National Strategic Plan for HIV Prevention, Care, and Treatment for Sex Workers, and it was updated in 2016 to provide more comprehensive coverage and access to anti-HIV treatments. ${ }^{22,23}$

In recent years, the HIV/AIDS new cases were most widely found among FSW in Africa. ${ }^{16,24-26}$ Also, the same results were obtained in the meta-analysis study conducted by Baral et al, ${ }^{27}$ who investigated the incidence of HIV/AIDS among FSWs in low-income countries. They found that the prevalence rate of the HIV/AIDS among FSWs in 50 low-income countries was equal to $11.8 \%$, which was higher than the prevalence rate obtained in the present study. The discrepancy between these results may be explained by higher exposure to HIV/AIDS, as well as the poor educational and preventive measures implemented to combat HIV in low-income nations.

Previously, Zhang et $\mathrm{al}^{28}$ investigated the prevalence of HIV/AIDS among FSWs across the six regions in China during 2000-2011 using meta-analysis. Their findings revealed that the prevalence of HIV/AIDS among FSWs has declined from $0.74 \%$ in 2000 to $0.40 \%$ with $95 \%$ confidence interval in 2011 . Zhang et $\mathrm{al}^{28}$ assumed that this declining trend may potentially be associated with interventional efforts and HIV prevention programs implemented in the country. According to the results of the present study and the study conducted by Zhang et al, ${ }^{28}$ it is obvious that the HIV/AIDS prevalence among FSW of Asian countries is relatively low.

Moreover, a study conducted by Chow et al, ${ }^{29}$ showed that comprehensive behavioral interventions were more effective, rather than health education only programs, to improve condom use and HIV testing uptake among FSW in China. According to their result, behavioral interventions improved condom use among FSW by 2.3-5.0- times compared with the pre-intervention period. Also, they found that behavioral intervention has resulted in a 4.6-fold HIV testing uptake among FSW in the past 12 months. Such a comprehensive intervention program has also raised the awareness of FSW on the HIV transmission modes, as well preventive measures they should take to avoid probable HIV exposure. Our results indicate the high rate of intravenous drug use among FSW (0.07\%) as an important risk factor for HIV transmission. Besides, infrequent use of condoms during their sexual intercourse with clients was also recognized as another important risk factor which makes them vulnerable to be infected with HIV.

\section{Conclusion}

The present study showed the high prevalence rate of HIV infection among FSWs. We assumed that FSW could act as a core group in HIV/AIDS transmission and propagation due to the high frequency as well as daily sexual relationships with different partners. Moreover, two important risk factors of infrequent condom use and prevalence of intravenous drug use among FSW highlights their role in HIV/AIDS transmission more than ever. Hence, comprehensive and global interventional programs need to be implemented to reduce the prevalence of HIV/AIDS among FSW and to prevent HIV propagation in societies.

One of the important limitations in this domain was the lack of access to some relevant studies, and some studies were not published in English. Unfortunately, it seems that the prevalence rate of HIV among FSW may be higher than that reported in the present study and in other studies, because the criminal nature of sex work in some countries as well as the Taboo make the results somehow unrealistic.

\section{Ethical approval}

Ethical approval was not required for this study; because this study is a meta-analysis.

\section{Acknowledgments}

The authors extend their gratitude to the Student Research Committee of Shahid Beheshti University of Medical Science for their kind support. No benefits in any form have been or will be received from a commercial party related directly or indirectly to the subject of this article.

\section{Disclosure}

The authors report no conflicts of interest in this work. 


\section{References}

1. Adler MW. Development of the epidemic. BMJ. 2001;322 (7296):1226-1229.

2. Granich R, Gupta S, Hersh B, et al. Trends in AIDS deaths, new infections and ART coverage in the top 30 countries with the highest AIDS mortality burden; 1990-2013. PLoS One. 2015;10(7): e0131353. doi:10.1371/journal.pone.0131353

3. Jenness SM, Neaigus A, Hagan H, Murrill CS, Wendel T. Heterosexual HIV and sexual partnerships between injection drug users and noninjection drug users. AIDS Patient Care STDS 2010;24(3):175-181. doi:10.1089/apc.2009.0227

4. Poundstone KE, Strathdee SA, Celentano DD. The social epidemiology of human immunodeficiency virus/acquired immunodeficiency syndrome. Epidemiol Rev. 2004;26(1):22-35. doi:10.1093/epirev/mxh005

5. Buchbinder SP. HIV epidemiology and breakthroughs in prevention 30 years into the AIDS epidemic. Top Antivir Med. 2011;19(2):38.

6. Wood E, Montaner JS, Chan K, et al. Socioeconomic status, access to triple therapy, and survival from HIV-disease since 1996. Aids. 2002;16(15):2065-2072.

7. Farr AC, Wilson DP. An HIV epidemic is ready to emerge in the Philippines. J Int AIDS Soc. 2010;13(1):16. doi:10.1186/1758-265213-16

8. Weniger $\mathrm{B}$, Limpakarnjanarat $\mathrm{K}$, Ungchusak $\mathrm{K}$, et al. The Epidemiology of HIV-Infection and Aids in Thailand (AIDS, VOL 5, PG S 71, 1991). Rapid Science Publishers 2-6 Boundary Row, London, England SE1 8NH; 1993. p. 149.

9. Bozicevic I, Voncina L, Zigrovic L, Munz M, Lazarus J. HIV epidemics among men who have sex with men in central and eastern Europe. Sex Transm Infect. 2009;85(5):336-342. doi:10.1136/ sti.2008.035436

10. Delpech V, Yin Z, Abernethy J, et al. The impact in the UK of the Central and Eastern European HIV epidemics. Epidemiol Infect. 2009;137(9):1266-1271. doi:10.1017/S0950268809002155

11. Reeves A, Steele S, Stuckler D, McKee M, Amato-Gauci A, Semenza JC. National sex work policy and HIV prevalence among sex workers: an ecological regression analysis of 27 European countries. Lancet HIV. 2017;4(3):e134-e40. doi:10.1016/S2352-3018(16) 30217-X

12. Shannon K, Strathdee SA, Goldenberg SM, et al. Global epidemiology of HIV among female sex workers: influence of structural determinants. Lancet. 2015;385(9962):55-71. doi:10.1016/S0140-6736 (14)60931-4

13. Maartens G, Celum C, Lewin SR. HIV infection: epidemiology, pathogenesis, treatment, and prevention. Lancet. 2014;384 (9939):258-271. doi:10.1016/S0140-6736(14)60164-1

14. Levi J, Raymond A, Pozniak A, Vernazza P, Kohler P, Hill A. Can the UNAIDS 90- 90-90target be achieved? A systematic analysis of national HIV treatment cascades. BMJ Global Health. 2016;1(2): e000010. doi:10.1136/bmjgh-2015-000010

15. Hariri S, McKenna MT. Epidemiology of human immunodeficiency virus in the United States. Clin Microbiol Rev. 2007;20(3):478-488. doi:10.1128/CMR.00006-07

16. Vandepitte J, Bukenya J, Weiss HA, et al. HIV and other sexually transmitted infections in a cohort of women involved in high risk sexual behaviour in Kampala, Uganda. Sex Transm Dis. 2011;38 (4):316. doi:10.1097/OLQ.0b013e3182000e47

17. Mahfoud Z, Afifi R, Ramia S, et al. HIV/AIDS among female sex workers, injecting drug users and men who have sex with men in Lebanon: results of the first biobehavioral surveys. Aids. 2010;24: S45-S54. doi:10.1097/01.aids.0000386733.02425.98

18. Kang D, Tao X, Liao M, et al. An integrated individual, community, and structural intervention to reduce HIV/STI risks among female sex workers in China. BMC Public Health. 2013;13(1):717. doi:10.1186/ 1471-2458-13-717
19. Mountain E, Pickles M, Mishra S, Vickerman P, Alary M, Boily MC. The HIV care cascade and antiretroviral therapy in female sex workers: implications for HIV prevention. Expert Rev Anti Infect Ther. 2014;12(10):1203-1219. doi:10.1586/14787210. 2014.948422

20. Group ISS. Initiation of antiretroviral therapy in early asymptomatic HIV infection. N Engl J Med. 2015;373(9):795-807. doi:10.1056/ NEJMoa 1506816

21. Cohen M, Chen Y, McCauley M, et al. Prevention of HIV-1 infection with early antiretroviral therapy. $N$ Engl J Med. 2011. doi:10.1056/ NEJMoa1105243

22. South African National AIDS Council. National Strategic Plan for HIV Prevention, Care and Treatment for Sex Workers. South Africa: South African National AIDS Council Pretoria; 2013.

23. South African National AIDS Council. The South African National Sex Worker HIV Plan, 2016-2019. South Africa: South African National AIDS Council Pretoria; 2016.

24. Vuylsteke B, Semdé G, Sika L, et al. HIV and STI prevalence among female sex workers in Cote d'Ivoire: why targeted prevention programs should be continued and strengthened. PLoS One. 2012;7(3): e32627. doi:10.1371/journal.pone.0032627

25. Afzal O, Lieber M, Dottino P, Beddoe AM. Cervical cancer screening in rural South Africa among HIV-infected migrant farm workers and sex workers. Gynecol Oncol Rep. 2017;20:18-21. doi:10.1016/j. gore.2016.12.011

26. Forbi JC, Entonu PE, Mwangi LO, Agwale SM. Estimates of human immunodeficiency virus incidence among female sex workers in north central Nigeria: implications for HIV clinical trials. Trans $R$ Soc Trop Med Hyg. 2011;105(11):655-660. doi:10.1016/j. trstmh.2011.08.001

27. Baral S, Beyrer C, Muessig K, et al. Burden of HIV among female sex workers in low-income and middle-income countries: a systematic review and meta-analysis. Lancet Infect Dis. 2012;12(7):538-549. doi:10.1016/S1473-3099(12)70066-X

28. Zhang L, Chow EP, Su S, et al. A systematic review and metaanalysis of the prevalence, trends, and geographical distribution of HIV among Chinese female sex workers (2000-2011): implications for preventing sexually transmitted HIV. Int J Infect Dis. 2015;39:7686. doi:10.1016/j.ijid.2015.08.014

29. Chow EP, Tung K, Tucker JD, et al. Behavioral interventions improve condom use and HIV testing uptake among female sex workers in china: a systematic review and meta-analysis. AIDS Patient Care STDS. 2015;29(8):454-460. doi:10.1089/ apc. 2015.0043

30. Abdelrahim MS. HIV prevalence and risk behaviors of female sex workers in Khartoum, north Sudan. Aids. 2010;24:S55-S60. doi:10.1097/01.aids.0000386734.79553.9a

31. Todd CS, Nasir A, Stanekzai MR, et al. HIV, hepatitis B, and hepatitis $\mathrm{C}$ prevalence and associated risk behaviors among female sex workers in three Afghan cities. Aids. 2010;24(02):S69. doi:10.1097/01.aids.0000386736.25296.8d

32. Strathdee SA, Lozada R, Martinez G, et al. Social and structural factors associated with HIV infection among female sex workers who inject drugs in the Mexico-US border region. PLoS One. 2011;6(4):e19048. doi:10.1371/journal.pone.0019048

33. Braunstein SL, Ingabire CM, Kestelyn E, et al. High human immunodeficiency virus incidence in a cohort of Rwandan female sex workers. Sex Transm Dis. 2011;38(5):385-394.

34. Xu J, Brown K, Ding G, et al. Factors associated with HIV testing history and HIV-test result follow-up among female sex workers in two cities in Yunnan, China. Sex Transm Dis. 2011;38(2):89. doi:10.1097/OLQ.0b013e3182000e47

35. Ramesh S, Ganju D, Mahapatra B, Mishra RM, Saggurti N. Relationship between mobility, violence and HIV/STI among female sex workers in Andhra Pradesh, India. BMC Public Health. 2012;12 (1):764. doi:10.1186/1471-2458-12-764 
36. Goldenberg SM, Chettiar J, Annick S, et al. Early sex work initiation independently elevates odds of HIV infection and police arrest among adult sex workers in a Canadian setting. $J$ Acquir Immune Defic Syndr. 2014;65(1):122. doi:10.1097/ QAI.0b013e3182a98ee6

37. Schwartz S, Papworth E, Thiam-Niangoin M, et al. An urgent need for integration of family planning services into HIV care: the high burden of unplanned pregnancy, termination of pregnancy, and limited contraception use among female sex workers in Côte d'Ivoire. $J$ Acquir Immune Defic Syndr. 2015;68:S91-S8. doi:10.1097/ QAI.0000000000000448

38. Deuba K, Anderson S, Ekström AM, et al. Micro-level social and structural factors act synergistically to increase HIV risk among Nepalese female sex workers. Int J Infect Dis. 2016;49:100-106. doi:10.1016/j.jijid.2016.06.007

39. Pando MA, Coloccini RS, Reynaga E, et al. Violence as a barrier for HIV prevention among female sex workers in Argentina. PLoS One. 2013;8(1):e54147. doi:10.1371/journal.pone.0054147

40. Qyra S, Basho M, Bani R, et al. Behavioral risk factors and prevalence of HIV and other STIs among female sex workers in Tirana, Albania. New Microbiol. 2011;34(1):105-108.

41. Argento E, Strathdee SA, Goldenberg S, Braschel M, Montaner J, Shannon K. Violence, trauma and living with HIV: longitudinal predictors of initiating crystal methamphetamine injection among sex workers. Drug Alcohol Depend. 2017;175:198-204. doi:10.1016/j.drugalcdep.2017.02.014

42. Corneli A, Lemons A, Otieno-Masaba R, et al. Contraceptive service delivery in Kenya: a qualitative study to identify barriers and preferences among female sex workers and health care providers. Contraception. 2016;94(1):34-39. doi:10.1016/j.contraception.2016.03.004

43. Decker MR, Wirtz AL, Baral SD, et al. Injection drug use, sexual risk, violence and STI/HIV among Moscow female sex workers. Sex Transm Infect. 2012;88(4):278-283. doi:10.1136/sextrans-2011-050171

44. Decker MR, Lyons C, Billong SC, et al. Gender-based violence against female sex workers in Cameroon: prevalence and associations with sexual HIV risk and access to health services and justice. Sex Transm Infect. 2016;92(8):599-604. doi:10.1136/sextrans-2015-052463

45. Fan YG, Liu JJ, Zhang YJ, Dai SY, Li MQ, Ye DQ. HIV, other sexually transmitted infections, and risk behaviors among female sex workers in Liuzhou, China. Inter J Gynecology Obstetrics. 2015;128 (1):18-22. doi:10.1016/j.ijgo.2014.07.024

46. Couture MC, Sansothy N, Sapphon V, et al. Young women engaged in sex work in Phnom Penh, Cambodia, have high incidence of HIV and sexually transmitted infections, and amphetamine-type stimulant use: new challenges to HIV prevention and risk. Sex Transm Dis. 2011;38(1):33. doi:10.1097/OLQ.0b013e3182000e47

47. Le LVN, Nguyen TA, Tran HV, et al. Correlates of HIV infection among female sex workers in Vietnam: injection drug use remains a key risk factor. Drug Alcohol Depend. 2015;150:46-53. doi:10.1016/ j.drugalcdep.2015.02.006

48. Dias S, Gama A, Fuertes R, Mendão L, Barros H. Risk-taking behaviours and HIV infection among sex workers in Portugal: results from a cross-sectional survey. Sex Transm Infect. 2015;91(5):346352. doi:10.1136/sextrans-2014-051697
49. Magnani R, Riono P, Saputro E, et al. Sexual risk behaviours, HIV and other sexually transmitted infections among female sex workers in Indonesia. Sex Transm Infect. 2010;86(5):393-399. doi:10.1136/ sti.2009.038059

50. Medhi GK, Mahanta J, Paranjape RS, Adhikary R, Laskar N, Ngully P. Factors associated with HIV among female sex workers in a high HIV prevalent state of India. AIDS Care. 2012;24(3):369-376. doi:10.1080/09540121.2011.608787

51. Wirtz AL, Peryshkina A, Mogilniy V, Beyrer C, Decker MR. Current and recent drug use intensifies sexual and structural HIV risk outcomes among female sex workers in the Russian federation. Int J Drug Policy. 2015;26(8):755-763. doi:10.1016/j. drugpo.2015.04.017

52. Silitonga N, Davies SC, Kaldor J, Wignall S, Okoseray M. Prevalence over time and risk factors for sexually transmissible infections among newly-arrived female sex workers in Timika, Indonesia. Sex Health. 2011;8(1):61-64. doi:10.1071/SH10038

53. Wang H, Brown KS, Wang G, et al. Knowledge of hiv seropositivity is a predictor for initiation of illicit drug use: incidence of drug use initiation among female sex workers in a high HIV-prevalence area of China. Drug Alcohol Depend. 2011;117(2-3):226-232. doi:10.1016/j. drugalcdep.2011.02.006

54. Wayal S, Cowan F, Warner P, Copas A, Mabey D, Shahmanesh M. Contraceptive practices, sexual and reproductive health needs of HIV-positive and negative female sex workers in Goa, India. Sex Transm Infect. 2011;87(1):58-64. doi:10.1136/ sti.2010.043158

55. Platt L, Grenfell P, Bonell C, et al. Risk of sexually transmitted infections and violence among indoor-working female sex workers in London: the effect of migration from Eastern Europe. Sex Transm Infect. 2011;87(5):377-384. doi:10.1136/ sti.2011.049544

56. Chen XS, Liang GJ, Wang QQ, et al. HIV prevalence varies between female sex workers from different types of venues in southern China. Sex Transm Dis. 2012;39(11):868-870. doi:10.1097/OLQ.0b013e3 $18264 \mathrm{c} 3 \mathrm{ba}$

57. Zhu J, Yuan R, Hu D, Zhu Z, Wang N, Wang B. HIV prevalence and correlated factors of female sex workers and male clients in a border region of Yunnan Province, China. Int J STD AIDS. 2018;29(5):424434. doi: $10.1177 / 0956462417730258$

58. Lu S, Cui Y, Guo W, Li D, Sun J. Epidemiological survey of prevalence of HIV infection, syphilis and hepatitis $\mathrm{C}$ in female sex workers and other 6 risk populations in tibet autonomous region. Zhonghua liu xing bing xue za zhi. 2017;38(7):921-925. doi:10.3760/cma.j.issn.0254-6450.2017.07.015

59. Okafor UO, Crutzen R, Ifeanyi O, Adebajo S, Borne H. HIV prevalence and high-risk behaviour of young brothel and non-brothel based female sex workers in Nigeria. BMC Res Notes. 2017;10 (1):380. doi:10.1186/s13104-017-2712-8

60. Kakchapati S, Paudel T, Maharjan M, Lim A. Systematic differences in HIV, syphilis and risk behaviors among street based and establishment based female sex workers in Kathmandu valley of Nepal. Nepal J Epidemiol. 2016;6(4):620. doi:10.3126/nje. v6i4.17256 


\section{Publish your work in this journal}

HIV/AIDS - Research and Palliative Care is an international, peerreviewed open-access journal focusing on advances in research in HIV, its clinical progression and management options including antiviral treatment, palliative care and public healthcare policies to control viral spread. The manuscript management system is completely online and includes a very quick and fair peer-review system, which is all easy to use. Visit http://www.dovepress.com/testimonials.php to read real quotes from published authors.

Submit your manuscript here: https://www.dovepress.com/hivaids—research-and-palliative-care-journal 